\title{
MANAJEMEN RISIKO BENCANA GEOLOGI
}

\author{
Dr. Drs. Bambang Sucipto, MM ${ }^{1,)}$ Dra. Yuyun Mulyati, M.Si. ${ }^{2)}$ \\ bambangsucipto0810@gmail.com ${ }^{1)}$, mulyati.yuyun@gmail.com ${ }^{2)}$ \\ 1.Dosen STIA Bandung \& Dosen Universitas Al-Ghifari \\ 2.Dosen Universitas Al-ghifari.
}

\begin{abstract}
Geological disasters can occur all over the world, including in this beloved Indonesian earth. There are many potential geological disasters in Indonesia, including landslides, flash floods, earthquakes, tsunamis, and volcanic disasters. The occurrence of geological disasters that occur especially in Indonesia can cause significant losses (risks). Various types of victims can be identified from each disaster incident. The amount of damage caused as a result of geological disasters, namely the worst is the loss of human life, then loss of property, as well as damage to the earth and the environment. The earth and the environment should be a unit that provides mutual benefits and does not give or cause harm.

There are several Geological disasters that were previously unpredictable and occurred suddenly, for example the tsunami disaster in Aceh that occurred in 2006, and landslides that occurred in several regions in Indonesia. However, there are some natural disasters that can be predicted from the start, for example, the possibility of flash floods in an area due to environmental damage due to land conversion. Minimizing the victims of geological disasters can be done through analysis through risk management. Analysis through methods, strategies and policies will provide benefits for the government, society and other parties with the aim of being able to anticipate the risk of geological disasters in order to reduce losses. Environmental damage due to geological disaster needs to be rearranged according to functions that are more beneficial to human welfare.
\end{abstract}

\section{Keywords: GEOLOGICAL DISASTER, RISK MANAGEMENT}

\section{PENDAHULUAN}

\section{Manajemen Bencana Geologi}

Hubungan Bumi dan Lingkungan.

Dalam kenyataannya bumi tidak dapat dipisahkan dengan lingkungan. Dengan demikian hubungan antara kebumian dan lingkungan tidak saja terdapat pada fenomena yang berkaitan dengan tatanan kehidupan melainkan terkait pula dengan aspek kelestarian lingkungan. Dalam perencanaan pembangunan dan pelaksanaan pembangunan wilayah dan nasional, tidak terlepas dari peranan geologi dan lingkungannya sehingga terjadi hubungan antara geologi-lingkungan. Sehingga faktor kebumian merupakan yang harus menjadi petimbangan utama. Perencanaan dan penataan perkotaan harus mengintegrasikan aspek ekonomi dan ekologi. Gagasan seperti menekankan pada pertimbangan masalah lingkungan.

Hubungan Bencana Geologi dan Lingkungan.

Mengulas masalah bencana geologi ternyata tidak dapat dipisahkan dengan lingkungan, ada beberapa bencana geologi di Indonesia, diantaranya bencana gempa bumi, tsunami, tanah 
longsor, amblasan tanah, dan letusan gunung berapi. Terjadinya bencana di Indonesia berpengaruh terhadap lingkungan geologi. Perubahan alih fungsi hutan sebagai salah satu keputusan pejabat publik dapat mempengaruhi lingkungan, dan kalo tidak hati-hati sering menimbulkan bencana geologi. Hubungan manusia dengan lingkungan hidup adalah sifatnya sirkuler dimana dalam kegiatan manusia sedikit banyak akan merubah lingkungan. Perubahan pada lingkungan pada gilirannya akan memengaruhi manusia.

Antara manusia dan lingkungan mempunyai sifat timbal balik. Saling memengaruhi, harusnya ada timbal balik yang positif, lingkungan yang sifatnya memberikan dukungan positif (pendukung) kepada keduanya. Bukan lingkungn yang sifatnya negatif (penghambat) atau yang dapat merugikan keduanya.

Dilihat dari fungsinya lingkungan adalah sbb :

a) Sebagai sumber daya (resources).

b) Alam lingkungan menyediakan bahan mentah (raw material) yang ditransformasikan dengan menggunakan energi untuk menghasilkan barang-barang dan jasa melalui proses produksi

c) Sebagai tempat kembalinya limbah (sink).

d) Aktifitas produksi dan konsumsi barang-barang dan jasa menghasilkan limbah atau produk sisa (waster product residual)

e) Sebagai sumber kesenangan/rekreasi (amenity service)

\section{Peran Geologi Lingkungan.}

Geologi Lingkungan adalah upaya memanfaatkan lingkungan geologi secara rasional untuk perlindungan manusia, harta benda dan lingkungannya dari bahaya yang mungkin ditimbulkan oleh lingkungan geologi tersebut, baik karena sifat alamiahnya maupun karena interaksi dengan kegiatan manusia. Penyelidikan geologi lingkungan menjadi penting, mengingat terdapat beberapa aspek dalam rangka pembangunan nasional yang berwawasan lingkungan harus dilakukan melalui penyelidikan geologi lingkungan, salah satunya untuk antisipasi risiko yang mungkin terjadi, dengan demikian bumi dan lingkungan tetap menjadi kesatuan yang saling memberikan manfaat dan kesejahteraan bagi masnusia.

Instansi yang menangani masalah mitigasi bencana geologi dan geologi lingkungan di Indonesia adalah Pusat Vulkanologi dan Mitigasi Bencana Geologi (PVMBG) dan Pusat Sumber Daya Air Tanah dan Geologi Tata Lingkungan, Badan Geologi (PSDATGTL), dan Kementerian ESDM. Ketiga Badan pemerintah tersebut merupakan institusi yang mengelola sumber informasi bagi pemangku kepentingan dan masyarakat banyak terutama yang berkaitan dengan bencana geologi.

Berdasarkan hasil beberapa Workshop/Seminar PVMBG, didapatkan data dan hasil bahwa masih terdapat potensi gempa bumi teknotik di Pulau Jawa, terutama di Pulau Jawa Bagian Utara, karena berada pada jalur zona penunjaman atau zona subduksi dan gerakan tanah dapat terjadi dikarenakan adanya alih fungsi hutan menjadi lahan yang ditanami tanaman ekonomis, sehingga hal tersebut akan menyebabkan hilangnya keseimbangan daya dukung tanah sehingga akan terjadi gerakan tanah di lokasi yang sama.

Kejadian Tsunami Aceh Tahun 2004, merupakan titik awal kesadaran masyarakat di Indonesia akan pentingnya mitigasi bencana. Dengan demikian adanya mitigasi bencana diharapkan risiko bencana yang muncul akan semakin kecil. 


\section{Faktor dan Risiko Lingkungan:}

Faktor lingkungan sebagian membantu dan sebagian merintangi atau menghambat untuk memenuhi kebutuhan kebutuhan dasar manusia. Faktor yang membantu atau memberikan dorongan positif disebut manfaat lingkungan, sedangkan yang bersifat merintangi atau menghambat disebut risiko lingkungan.

Untuk mengurangi risiko bencana, dengan demikian salah satunya adalah sosialisasi kepada masyarakat tentang bahaya, dampak dan mitigasi bencana geologi.

Menurut Addinul apabila diklasifikasikan ada 4 jenis masalah lingkungan di Indonesia, yaitu:

1. Deforestrasi

2. Degradasi lahan

3. Kekurangan air

4. Polusi udara dan air

Dari permasalahan tersebut, kalau dikaji banyak hal yang dapat diketahui oleh manusia dan cara mengantisipasinya, misalnya masalah kekurangan air bersih. Aspek kekurangan air dalam konteks bencana geologi adalah menghilangnya sumber air bersih, untuk jangka sesaat atau jangka yang cukup lama, karena akibat tertimbun, longsoran, reruntuhan atau rusaknya fasilitas sarana umum.

Contoh lainnya yang terjadi di Indonesia yang masih dalam ingatan masyarakat adalah bencana lumpur Sidoarjo, masyarakat sekitar yang melakukan pemboran air, tidak memperoleh air tetapi yang didapat adalah semburan gas. Yang menjadi pertanyaan adalah kemanakah sumber air bersih tersebut?

Degradasi lahan juga merupakan salah satu akibat dari bencana geologi. Berhektar-hektar hamparan sawah, perkebunan dan ladang petani menjadi rusak, sehingga berakibat dalam jangka waktu lama tidak dapat dimanfaatkan atau tidak berproduksi. Dengan demikian terdapat hubungan antara antara bencana geologi dengan lingkungan.

\section{Manajemen risiko bencana geologi.}

Bencana geologi adalah bencana yang terjadi dipermukaan bumi atau disebabkan oleh gerakan tanah atau aktifitas dari dasar bumi yang muncul ke permukaan. Arti geologi itu sendiri adalah ilmu yang mempelajari segala hal tentang bumi. Bencana geologi yang murni dari aktifitas di permukan bumi tanpa dipengaruhi oleh manusia adalah gempa bumi, tsunami dan gunung meletus, dan tanah longsor. Bencana geologi ini mempunyai dampak, yaitu kerusakan yang diakibatkan dari bencana tersebut karena musibah bencana geologi tersebut tidak dapat diprediksi kapan datangnya.

Geologi lingkungan adalah upaya memanfaatkan lingkungan geologi secara rasional untuk perlindungan manusia, harta benda dan lingkungannya dari bahaya yang mungkin ditimbulkan oleh lingkungan geologi tersebut, baik karena sifat alamiahnya maupun karena interaksi dengan kegiatan manusia. Lingkungan atau sering dikenal dengan lingkungan hidup, adalah semua benda hidup dan mati serta seluruh kondisi yang ada di dalam ruang yang kita tempati. Dalam pengertian lain lingkungan diartikan adalah kombinasi antara kondisi fisik yang mencakup keadaan sumber daya alam seperti tanah, air, energi surya, mineral, serta flora dan fauna yang tumbuh di atas tanah maupun di dalam lautan, dengan kelembagaan yang meliputi ciptaan manusia seperti keputusan bagaimana menggunakan lingkungan fisik tersebut.

Perubahan lingkungan yang diakibatkan dari bencana geologi mempengaruhi mahluk hidup. 
Dari bukti sejarah hal ini tentu dapat diketahui bersama bahwa akibat bencana geologi telah menimbulkan kepunahan mahluk dan lingkungan. Bencana geologi tidak dapat dipisahkan dari lingkungan geologi. Keduanya merupakan sesuatu yang mempunyai interaksi. Dari aspek lingkungan dan bencana geologi, dapat dijelaskan beberapa hal yang menurut kita dan masyarakat perlu mengetahui secara umum. Dari aspek bencana geologi, telah dapat diketahui dan dirasakan oleh masyarakat Indonesia, berbagai macam jenis bencana geologi, telah terjadi, beberapa diantaranya yang belum lama adalah bencana banjir bandang yang terjadi di Jawa Barat yaitu Garut dan Ciwidey, serta di Ponorogo Jawa Timur.

Akibat dari bencana geologi tersebut adanya korban, baik korban jiwa mauoun harta benda dengan kerugian yang jumlahnya tidak sedikit, disertai dengan rusaknya lingkungan, rusaknya infrastruktur dan berbagai kerugian lainnya yang menjadikan masyarakat menjadi kurang berdaya dalam menata kehidupan berikutnya. Dalam mengatasi permasalahan yang ditimbulkan akibat dari bencana geologi tersebut pemerintah menyediakan beberapa sumber daya, yaitu sumber daya manusia, sumber daya uang (anggaran) dan sumber daya lainnya.

Upaya Pemerintah dalam mengatasi apabila terjadinya kerugian akibat adanya bencana geologi agar tidak memakan korban baik jiwa maupun harta benda berupa tanah, infrastruktur/bangunan, hewan ternak, kebun sayuran, dokumen berharga, pakaian dan lainlainya serta rusaknya lingkungan hidup. Pemerintah menerapkan manajemen risiko yang bertujuan untuk mengantisipasi kerugian yang dikenal dengan risiko yang dialami oleh masyarakat dan pemerintah. Hal ini karena risiko tidak dapat dihilangkan tetapi dapat diminimalkan.

Risiko didefinisikan "the adverse impact on probability of seveal distinct sources of uncertainly”, sebagai ketidakpastian yang ditimbulkan oleh adanya perubahan. Manajemen risiko ini dapat dilakukan dengan dua metode, yaitu manajemen pra bencana dan manajemen pasca bencana geologi.

Manajemen risiko yang dilakukan sebelum bencana itu terjadi dapat dilakukan dengan berbagai cara:

1).Sosialisasi

2).Koordinasi

3).Penerbitan peta Kawasan Rawan Bencana (KRB)

4).Pemberian patok-patok batasan yang kemungkinan terdampak

5).Penyiapan sumber daya, yang terdiri darisumber daya manusia, uang/ anggaran, sarana dan peralatan,

6).Membuat jalur evakuasi

Sedangkan pada pasca bencana dan rusaknya lingkungan serta kerugian masyarakat, maka dilakukan dengan berbagai cara:

1) Penanganan evakuasi

2) Penanganan korban

3) Pendirian dapur umum

4) Pendirian fasilitas kesehatan

5) Penyediaan air bersih, MCK

6) Konseling bagi anak-anak

7).Penyediaan rumah hunian sementara/pengungsian

8).Pembangunan infrastruktur 
9).Ketersediaan keamanan

10).Koordinasi lintas sektor

11).Penyediaan dan pencairan anggaran

Secara bahu membahu seluruh kekuatan sipil, Polisi, TNI, LSM, instansi terkait terkonsentrasi, disekitar lokasi bencana. Hal ini dimaksudkan untuk penanganan bencana dan juga mengurangi risiko yang lebih besar/banyak lagi, contohnya fasilitas kesehatan diperlukan untuk menangani korban dan kemungkinan wabah penyakit yang akan timbul pasca bencana. Serta diperlukan adanya konseling untuk memberikan bimbingan bagi anak-anak untuk mengurangi trauma. Dan upaya lainnya yang bertujuan untuk mengurangi risiko.

\section{Kondisi Empiris Manajemen Risiko Bencana Geologi}

Substansi dari judul ini sudah pernah dibahas dalam majalah, media, taklkshow, seminar dan sejenisnya. Namun, masih ada sebagian orang yang perlu mengerti apa sebetulnya risiko bencana geologi, dan bagaimana manajemen risiko bencana geologi harus dilakukan dikaitkan dengan lingkungan.

Tulisan semacam ini sudah diawali dengan pengertian yang umum mengenai pengertian atau definisi geologi lingkungan, lingkungan dan manajemen risiko. Manajemen dari kata to manage, kita ambil satu pengertian saja to manage yang berarti "mengendalikan" yang selanjutnya kita gunakan berkaitan dengan Manajemen Risiko Bencana Geologi.

Pengertian manajemen mempunyai banyak arti, diantaranya :

1.Seni menggerakan sumber daya

2.Seni untuk mengalokasikan sumber daya organisasi

3.Proses pencapaian tujuan organisasi secara efektif dan efisien

4.Bagaimana mencapai tujuan dengan melalui atau bersama dengan orang-orang lain.

Pengertian manajemen yang digunakan dalam artikel ini adalah manajemen yang diartikan sebagai suatu pengendalian. Pengendalian adalah sebuah metode, prosedur dan strategi organisasi yang digunakan untuk menjamin bahwa pelaksanaan sesuai dengan strategi dan kebijakan.

Dengan demikian substansi manajemen risiko bencana geologi dimaknai sebagai upaya bagaimana melakukan suatu kegiatan untuk mengendalikan risiko bencana geologi dengan berbagai metode, strategi dan kebijakan.

Pengendalian Bencana Geologi

Pertanyaan yang muncul adalah mengapa bencana geologi harus dikendalikan?

a. Bisakah risiko dikendalikan?

b. Siapa yang mengendalikan?

c. Bagaimana cara mengendalikan?

d. Apa tujuan mengendalikan risiko bencana geologi?

e.Apa kaitannya bencana geologi dengan lingkungan?

Pertanyaan-pertanyaan tersebut harus dijelaskan:

Risiko dalam semua jenis dan bentuknya secara umum tidak dapat dihilangkan, oleh karena itu risiko hanya dapat diperkecil. Pertanyaan kemudian muncul, apakah bencana geologi dapat dikendalikan? 


\section{Jenis Bencana Geologi}

Dari banyak literatur yang dimaksud dengan bencana geologi adalah bencana alam yang terjadi di permukaan bumi seperti gempa bumi, tsunami, tanah longsor dan gunung meletus. Gempa bumi dan gunung meletus terjadi di hanya sepanjang jalur-jalur pertemuan lempeng teknonik di darat atau di lantai samudra.

Bencana-bencana yang ditimbulkan oleh geologi, meliputi :

a) rusaknya lingkungan

b) korban jiwa manusia

c) flora dan fauna

d) hilangnya harta benda lainnya seperti uang, perhiasan, binatang ternak dan dokumen atau surat-surat berharga.

\section{Pergerakan Sesar Lembang}

Pergerakan Sesar lembang merupakan potensi bencana geologi sebagaimana pendapat akhli Teknik Geodesi ITB Dr. Irwan Meilano, ST. MSc. yang dimuat dalam Gala Media tanggal 27 Mei 2017 halaman 6, menyampaikan bahwa Patahan Lembang memiliki kekuatan 6,5 sampai 7 skala Richter (SR). Dengan dampaknya bisa menyerupai gempa bumi di Bantul, Provinsi Yogyakarta (2006) atau Pidie Jaya, Provinsi Nanggroe Aceh Darusalam (2016). Dengan magnitudo 6,5 sampai 7 SR, ribuan penduduk yang tinggal di sepanjang Patahan Lembang harus mulai waspada. demikian disampaikan dalam pemahaman dan edukasi mengenai potensi bahaya dari Patahan Lembang di Fakultas Kedokteran Unjani, Rabu (24 Mei 2017).

Pendapat ini seharusnya tidak terlalu membuat masyarakat khawatir apabila infrastruktur bangunannya dalam kondisi baik. Selama ini korban bencana gempa bumi itu karena tertimpa reruntuhan bangunan. Bagaimana dengan Lembang, sebagai awalnya, dijelaskan goncangan akan sangat terasa, tetapi kalau struktur bangunannya sesuai dengan kaidah rekayasa bangunan, goncangan akan terasa tetapi tidak menimbulkan kerusakan parah. Masih dalam tulisannya, Patahan Lembang tidak memengaruhi aktivitas Gunung Tangkuban Perahu yang juga ada di Lembang. Patahan Lembang memiliki panjang sekitar 29 kilometer, membentang dari bukit Loceng di Desa Sunten Jaya, Kecamatan Lembang, Kabupaten Bandung, Barat (KBB) hingga ke Padalarang.

Dari simulasi yang dilakukan dampak gempa sangat mengejutkan, yaitu KBB, Kota Bandung, Kota Cimahi dan Wilayah Bandung Selatan akan terkena dampaknya. Berbagai informasi dari berbagai sumber Patahan Lembang terus bergerak hingga mencapai 4 milimeter per tahun. Merujuk pada fakta bahwa patahan ini berada di tengah kawasan padat penduduk, sangat mungkin dampak dari gempa yang dihasilkan bisa menimbulkan banyak korban jiwa dan lingkungan.

Ada hal yang perlu diketahui masyarakat, kalau infrastruktur dibangun dengan baik, seharusnya tidak perlu khawatir. Apalagi bangunan yang dibuat memenuhi kaidah rekayasa bangunan sesuai SNI. Bagaimana antisipasi masyarakat terhadap kemungkinan adanya dampak dari Patahan Lembang ini, maka Basarnas telah siap mengantisipasi dampak Patahan Lembang. Evakuasi akan segera dilakukan oleh Basarnas mengacu pada UU Nomor 29 Tahun 2014 Tentang Pencarian dan Pertolongan. Berkaitan dengan potensi bencana dari Patahan Lembang, BASARNAS sudah mempersiapkan segala sesuatunya, seperti peralatan yang memadai, 
terutama sumber daya manusia (personel) yang sudah terlatih. Pasalnya tidak semua orang memahami bagaimana caranya menangani bencana.

Terhadap pendapat di atas dimuat disini tidak lain adalah merupakan bagian dari sosialisasi yang perlu diketahui dan dipahami oleh masyarakat Bandung sekitanya dan Pemerintah pada umumnya.

\section{Risk Assessment (Penilaian Risiko).}

Penilaian risiko adalah menilai dampak dari events (kejadian atau keadaan) dapat mengganggu pencapaian dari objektif. Besarnya dampak dapat diketahui dari inherent dan residual risk serta dapat dianalisis dalam dua perspektif, yaitu likelihood (kecenderungan atau peluang) dan impact/consequence (besaran dari terealisasinya risiko). Dengan demikian, besaran risiko atas setiap kejadian merupakan perkalian antara likelihood dan consequnce. Dalam melakukan penilaian risiko dapat menggunakan dua teknik yaitu qualitative technique dan quantittive technique.

Dalam implementasi qualitative technique menggunakan beberapa tools, seperti selfassessment (low, medium, high), questiannaires, dan internal atau internal audite reviews. Adapun quantitative techniques dan berbentuk angka yang diperoleh dari tools, seperti probability based, non-probabilistic models (optimalkan hanya asumsi consequence) dan benchmarking. Perlu digaris bawahi bawa penilaian risiko setiap aktivitas akan menghasilkan informasi berupa peta dan angka risiko.

Hal yang perlu dicermati adalah events relationships atau hubungan antara kejadian/keadaan. Events yang terpisah mungkin memiliki risiko kecil. Akan tetapi, apabila digabungkan dapat menjadi signifikan. Demikian pula, risiko yang mempengaruhi banyak lingkungan perlu dikelompokkan dalam common event categories dan dinilai secara aggregate.

\section{Risk Response (Sikap atas Risiko).}

Manajemen atau organisasi, institusi yang terkait dengan hasil penilaian risiko, harus menentukan sikap Risk Reponse berupa:

1. Avoidance, yaitu dihentikannya aktivitas yang dapat menyebabkan risiko.

2. Reduction, yaitu mengambil langkah langkah untuk mengurangi likelihood atau impact risiko

3. Sharing yaitu mengalihkan atau menanggung bersama atau sebagian dari risiko dengan pihak lain.

4. Acceptance, yaitu menerima risiko yang terjadi, dengan tidak mengambil langkah-langkah tindakan.

Namun dalam mengambil sikap (response), perlu dipertimbangkan faktor-faktor seperti pengaruh setiap response terhadap risk likelihood dan impact, respon yang optimal sehingga bersinergi dengan pemenuhan risk appertite and teolerance, analist cost versus benefit, dan kemungkinan peluang (opportunities) yang dapat timbul setiap risk response.

1. Avoidance, yaitu dihentikannya aktivitas yang dapat menyebabkan risiko. Dapatkah reisiko dihentikan ? Diidentifikasi ya dan diambil langkah langkah.

Identiffikasi terhadap bencana geologi tentu dapat dilakukan sejak dini, banyak data, fenomena dan kejadian bencana geologi dimuka bumi Indonesia khususnya. Baik yang telah terjadi maupun yang kemungkinan akan terjadi.

Sesar Lembang merupakan salah satu contoh hasil identifikasi potensi bencana geologi 
yang kemungkinan akan terjadi. Dan apabila sesar Lembang terjadi maka kemungkinan terjadi bencana untuk wilayah Kota Bandung, Kabupaten Bandung Barat dan sekitarnya.

2. Reduction, yaitu mengambil langkah langkah untuk mengurangi likelihood atau impact risk.

Langkah-langkah nyata yang sudah diambil dan terus dilakukan oleh instansi-instansi terkait berkaitan dengan pengurangan risiko. Penelitian dan persiapan dilakukan oleh para akhli secara kontinu dan masif.

Dalam pada itu institusi seperti:

a). Badan Geologi Kementerian Energi dan Sumber Daya Mineral, Institut Teknologi Bandung (ITB).

b). BASARNAS

c).Badan Nasional Penanggulangan Bencana (BNPB) dan

d).Badan Penanggulangan Bencana Daerah (BPBD) baik Propinsi dan Kabupaten/Kota terkait akan menyiapkan langkah langkah tepat, cepat dan terbaik.

Belum lagi institusi Kepolisian dan TNI secara bahu-membahu akan turun untuk melakukan evakuasi dalam rangka mengurangi risko bencana. Rencana pengurangan risiko bencana geologi sudah dipetakan, sudah disosialisasikan oleh para pihak terkait, dan dengan adanya peta Kawasan Rawan Bencana (KRB) dan hasil penelitian para akhli yang sudah disosialisasikn, diseminarkan akan dapat membantu pihak Pemerintah dan pihak terkait untuk mengurangi risko bencana geologi.

Terbaru, pada bulan April 2017 telah dilaksanakan Rapat oleh Pemerintah Daerah Propinsi Jawa Barat dengan mengundang salah satunya adalah adan Badan Geologi. Rapat dimaksud dalam rangka Pembangunan Bandung Utara Transport Road (BUTR). Langkah yang sangat tepat BAPPEDA Propinsi Jawa Barat mengudang para akhli dari institusi terkait, karena dari peta rencana pembangunan BUTR melewati Sesar Lembang, yang tentunya apabila ini dilanjutkan tanpa kajian dari sisi struktur tanah atau geologi teknik dan geologi lingkunga akan sangat berbahaya dan mempunyai risiko yang sangat besar.

Badan Geologi menyampaikan kajian yang berkaitan dengan sesar Lembang, yang mempunyai potensi bencana geologi dan tentunya institusi seperti institut Teknologi Bandung akan memberikan kajian dari aspek geologi sebagaiman disampaikan oleh Badan Geologi.

1. Sharing yaitu mengalihkan atau menanggung bersama atau sebagian dari risiko dengan pihak lain.

Sharing dimaksudkan adalah untuk saling memberi informasi terhadap jenis bencana geologi di suatu daerah oleh Pemerintah Daerah terkena bencana geologi, dengan Pemerintah Derah lain yang mempunyai potensi bencana geologi.

Sharing disini dapat diberikan dari sisi:

a).Sosialisasi bencana geologi secara umum

b).Kesiapan penanganan bencana geologi

c).Koordinasilintas Kementerian/Lembaga

d).Penentuan lokasi evakuasi

e).Penanganan korban bencana geologi

f).Pembuatan dapur umum

g).Penyediaan fasilitas lingkungan pendukung seperti air bersih, Listrik, sarana MCK 
h).Pembiayaan/anggaran

i).Pengelolaan bantuan, baik sumber daya manusia, uang/anggaran, logistik dan lainya yang bersumber dari dalam negeri maupun luar negeri

Dalam mengantisipasi bencana geologi, mengapa sharing dilakukan? Ini harus terjawab karena setiap daerah mempunyai karakteristik lokasi/medan yang berbeda, jumlah penduduk dan lingkungan yang berbeda, kesadaran masyarakat yang berbeda tentu penanganan berbeda pula. Dari sharing ini Pemerintah Pusat dan setiap Pemerintah Daerah akan mengalokasikan sumber daya yang berbeda, tetapi ditujukan semata-mata untuk ngurangi bencana geologi dan rusaknya lingkungan.

2. Acceptance, yaitu menerima risiko yang terjadi, dengan tidak mengambil langkah-langkah tindakan.

Adalah sangat tidak mungkin dan tidak arif, apabila hal ini dilakukan. Artinya tidak ada persiapan apapun untuk mengurangi bencana geologi, di mana bencana geologi menimbulkan korban manusia, harta benda, tumbuh-tumbuhan, dokumen surat-surat berharga dan lingkungan rusak.

Sosialisasi sudah dilakukan, Peta Kawasan Rawan Bencana (KRB) sudah dikirim dan diterima oleh Pemerintah Daerah terkait, potensi bencana geologi sudah diketahui. Tetapi upaya untuk menanggulangi tidak ada, maka hal ini merupakan suatu hal yang sangat kurang bijak ditinjau dari sisi manajemen risko.

Pasti Pemerintah Pusat, Pemerintah Daerah dan institusi terkait termasuk Lembaga Swadaya Masyarakat akan berupaya bagaiamana dapat mengurangi atau meminimalisir bencana geologi. Secara khusus dalam pendapat yang sering disampaikan oleh Pakar Kebencanaan Dr. SuronoMantan Kepala Pusat Vulkanologi dan Mitigasi Bencana Geologi yang juga mantan Kepala Badan Geologi dan pernah menduduki jabatan Tenaga Akhli Kebencanaan dan Tata Ruang Kementerian Energi dan Sumber Daya Mineral berkali-kali menyampaikan bahwa risiko bencana tidak dapat dihilangkan, yang dapat dilakukan adalah mengurangi atau memperkecil risiko. Tentunya sependapt dengan pemikiran tersebut.

\section{Penangan Risiko (Risk Control).}

Terdapat beberapa metode dalam penanganan risiko (risk control) bencana geologi, yaitu :

- Menghindari risiko

- Megendalikan risiko

- Memisahkan risiko

- Melakukan kombinasi atau pooling

-Memindahkan risiko

Menghindari risiko. Upaya menghindari risiko secara totalitas sampai dengan nihil tidak bisa dilakukan, yang dapat dilakukan adalah menghindari risiko yang lebih besar.

Mengendalikan risiko, banyak metode yang dapat dilakukan untuk mengendalikan risiko bencana geologi:

a) Sosialisasi bencana geologi dan risiko bencana geologi

b)Petakan jenis risiko yang mungkin terjadi

c)Dibuat beberapa alternatif tindakan yang perlu dilakukan, dapat dilakukan dengan membuat jalur evakuasi, proses evakuasi dan penanganan pasca evakuasi 
d)Menyiapkan sumber daya manusia untuk menangani bencana geologi

Tindakan Evaluasi Pasca Bencana Geologi Secara Konspetual.

Memisahkan risiko, tindakan ini adalah untuk memisahkan risiko terhadap orang/masyarakat dan harta benda lainnya. Harus dibedakan dalam upaya penyelamatan terdahap bencana geologi, yang tidak tahu kapan akan terjadi, bagaimana akan terjadi maka pemisahan risiko harus dibedakan memisahkan untuk menyelamatkan jiwa orang/masyarakat dengan harta benda.

Prioritas di atas adalah menyematkan orang, diri sendiri, keluarga. Selagi itu memungkinkan untuk dilakukan menyelamatkan harta benda, yang sangat mungkin dilakukan adalah menyelamatkan benda yang mempunyai nilai tinggi dan mudah diselamatkan misalnya emas, surat-surat berharga. Langkah selanjutnya secara umum menyelamatkan hewan peliharaan seperti sapi, kerbau kambing dan sejenisnya. Memindahkan risiko, tindakan ini sifatnya sulit untuk dilakukan. Mengingat bencana geologi datangnya tidak dapat dipresiksi.

Melakukan kombinasi atau pooling adalah kombinasi penanganan risiko dengan menyiapkan metode yang terbaik untuk menyelamatkan masyarakat dan harta benda, tentunya ini dilakukan dengan penyiapan infrastruktur dan fasilitas lingkungan yang mudah dimanfaatkan oleh masyarakat apabila bencana geologi terjadi. Semua metode ini tujuan dan manfaatnya adalah dalam rangka mengurangi risiko bencana geologi. Jangan menimbulkan rasa takut dan kepanikan kepada masyarakat. Upaya sosialisasi terhadap dampak dari risiko bencana geologi yang diberikan oleh Pemerintah kepada masyarakat, harus memberikan pembelajaran secara luas tentang pemahaman bencana geologi secara umum dan dampak atau akibat yang ditimbulkan. Siapkan sosialisasi yang memberi pengetahun, bukan sebaliknya dengan sosialisasi bencana geologi menimbulkan rasa takut pada masyarakat, atau masyarakat menjadi stres/depresi.

Sebaliknya dengan sosialisasi ini, diharapkan masyarakat semakin sadar akan adanya bahaya bencana geologi dan dengan memahami bencana geologi, masyarakat mampu mengendalikan diri dan keluarganya agar selalu waspada atau siap apabila sewaktu-waktu terjadi bencana geologi. Di mana bencana geologi tidak dapat diprediksi datangnya, namun dampak yang dimbulkan dapat diprediksi tentunya dengan suatu metodologi imliah.

\section{Pemberdayaan Masyarakat:}

Mengingat potensi bencana geologi dapat menimbulkan risiko bagi masyarakat dan rusaknya lingkungan, maka pemberdayaan masyarakat perlu dilakukan. Geopark menuju Merangin 170 Pemberdayaan Masyarakat (comunity development) adalah usaha menolong seseorang agar mampu memajukan dirinya sendiri (the self help oriented phylosophy).

\section{Pembahasan}

Pembahasan mengenai manajemen risiko bencana geologi dan lingkungan ini disajikan dari contoh dari bencana yang terjadi di Ponorogo. Terdapat belasan warga terkubur akibat tertimbun longsoran, tidak sedikit masyarakat yang terluka akibat longsor di Desa Banaran, Kecamatan Pulung Ponorogo. Infrastruktur, harta benda hilang seperti emas, dokumen, mobil, tanah dan bangunan rusak, lahan pertanian atau lingkungan tidak dapat berfungsi.

Dalam kondisi seperti ini maka, langkah-langkah konkret yang dilakukan oleh Pemerintah Pusat Lintas Kementerian/Lembaga, Pemerintah Daerah dan masyarakat mengerahkan seluruh sumber daya yang ada dan telah disiapkan pasca bencana sebagaimana disebutkan sebelumnya, 
yaitu :

a). Evakuasi korban,

b). Pemakaman

c). Pertolongan kesehatan

d). Pendirian dapur umum

e). Penyediaan keamanan/rasa aman

f). Fasilitas air bersih, penerangan

g). Fasilitas lingkungan lainnya

h).Dan lainnya untuk meringankan penderitaan korban.

Bencana geologi telah merusak lingkungan atau setidaknya mempengaruhi kondisi lingkungan.

Antisipasi berikutnya agar kejadian tidak terulang di wilayah tersebut adalah:

1).Memberikan sosialisasi kepada masyarakat

2). Merelokasi penduduk

3). Pemerintah menyediakan tanah dan bangunan

4)Pemerintah menyediakan kebutuhan makan dan minum untuk jangka waktu terbatas

5)Pemerintah menyediakan infrastrutkur

6)Pemerintah memberikan jaminan hidup untuk waktu tertentu

7)Pemerintah menjamin rasa aman masyarakat korban bencana

8)Penataan lingkungan di wilayah yang terkena bencana

9)Pemerintah memikirkan bagaimana kehidupan masyarakat pada hari-hari berikutnya

Hal ini semata-mata untuk mengurangi risiko bencana agar apabila terjadi bencana geologi susulan tidak bertambah korban dalam segala bentuknya.

\section{Kesulitan Pada Penanganan Pasca Bencana}

Pemerintah Pusat, Pemerintah Daerah dan masyarakat disekitar daerah rawan bencana secara umum tentu mengetahui apa yang harus dilakukan apabila bencana geologi terjadi. Tetapi dalam keyataannya, mengingat bencana geoloi tidak diketahui kapan akan terjadi, maka timbul korban yang sangat banyak.

Beberapa kesulitan dalam rangka evakuasi, proses memberikan pertolongan dan penyelamatan warga adalah:

a).Kalau bencana terjadi malam hari, gelap, listrik terputus

b).Longsoran tanah yang begitu banyak

c).Medan yang sulit dilewati

d). Keterbatasan penyediaan peralatan berat dalam waktu singkat

e).Apabila bersamaan turun hujan besar, cuaca tidak mendukung

f). Banjir bandang yang sangat dahsyat

Permasalahan ini harus disikapi oleh Pemerintah Daerah dengan menyiapkan segala sumberdaya diantaranya Tim Reaksi Cepat Tanggap Darurat Bencana atau sejenisnya.

Mengingat bencana ggeologi merusak lingkungan, maka langkah berikutnya dalam penataan lingkungan, Pemerintah Daerah setempat telah berkomitmen untuk lokasi tanah longsor di Desa Banaran, Kecamatan Ulung, Kabupaten Ponorogo akan difungsikan kembali menjadi lahan pertanian yang sepertinya masih memungkinkan. Karena kalau digunakan tempat tinggal lagi, 
sepertinya sudah tidak layak. Pemerintah Daerah harus memikirkan pengembalian fungsi lahan tersebut sebagai lahan pertanian.

Penetapan agar dilokasi tersebut tidak menjadi lahan hunian tentunya meperhatian beberapa faktor, dan salah satunya mempetimbangkan masukan dari instansi terkait dalam hal ini Badan Nasional Penanggulangan Bencana, dan Badan Geologi Kementerian Energi dan Sumber Daya Mineral.

Dengan demikian kelestarian lingkungan, tetap terjaga dan dapat memberikan manfaat kesejahteraan bagi masyarakat. Sehingga hubungan antara bumi dan lingkungan tetap terjalin harmonis saling mendukung positif.

\section{Kesimpulan:}

Bumi dan lingkungan yang terdiri dari manusia, binatang (mahluk hidup), tumbuh-tumuhan, sungai, dan lainnya (mahluk tidak hidup) harus berinteraksi saling memberikan manfaat. Bencana geologi seperti gempa bumi, tsunami, tanah lonsor, banjir bandang, gunungapi meletus merupakan suatu yang dampaknya dirasakan manusia, karena secara umum memberikan kerugian pada masyarakat. Korban meninggal dunia terkubur, terseret banjir, terkena reruntuhan dan sebagaianya serta rusaknya lingkungan manusia. Salah satu contoh banjir bandang dan tanah longsor di Kabupaten Ponorogo.

Analisis untuk penanganan bencana geologi, dan kerusakan lingkungan agar tidak menimbulkan kerugian (risiko) yang lebih besar dapat diantisipasi sebelum terjadi bencana dan setelah terjadi bencana. Berbagai strategi dan kebijakan dapat dilakukan, dalam rangka meminimalisir risiko dengan manajemen risiko. Karena risiko bencana geologi tidak dapat dihilangkan.

Penataan daerah terdampak bencana geologi perlu terus dilakukan dalam rangka penataan lingkungan, meperbaiki infrasturkur dan fasilitas umum lainnya yang rusak agar tetap memberikan manfaat bagi kehidupan masyarakat dikemudian hari.

\section{DAFTAR PUSTAKA}

Abdurahman, Oman. 2015 Geokonservasi Indonesia, Badan Geologi, Bandung

Adisasmita, R. 2010. Pembangunan Kelautan \& Kewilayahan, Graha Ilmu, Yogyakarta.

Bambang Sucipto, 2020, Manajemen Strategic, Ars University, Bandung

Buranda, J.P., 2009. Geologi, IKIP Malang, Malang

Hadinoto, Kusudianto. 2008. Perencanaan Pengembangan Daerah, UI Press. Jakarta

Hatmoko, 2010. Sistem Pendukung Untuk Pengambilan Keputusan Untuk Masalah Alokasi Air Tanah, PAU UGM, Yogyakarta

Herman Darmawi, 2016, Manajemen Risiko Edisi 2, Bumi Aksara, Jakarta

J. David Hunger \& Thomas, Whellen, 2013. Manajemen Strategis, Andi, Yogyakarta

Komoo, Ibrahim. 2011. Conservation Geology, Lestari, UKM Malaysia

Lingkungan, Banyumedia Publishing, Malang

Oktariadi, Oki.2011. Menuju Geopark Merangin, Badan Geologi, Bandung

Rahardjo Adisasmita, 2010, Pembangunan Kawasan dan Tata Ruang, Graha Ilmu, Yogyakarta

Setia Mulyawan, 2015, Manajemen Risiko, Pusaka Setia, Bandung, 2015

Otto Sumarwoto, 2004, Ekologi, Lingkungan Hidup dan Pembangunan, Jambatan,Jakarta

Oki Oktariadi, Menuju Geopark Merangin, Propinsi Jambi, Badan Geologi KESDM, Bandung, 2011.

Otto Sumarwoto, Ekologi, Lingkungan Hidup dan Pembangunan, Jambatan, Jakarta, 2004

Rahardjo Adisasmita, Pembangunan Kawasan dan Tata Ruang, Graha Ilmu, Yogyakarta, 2010 
Setia Mulyawan, Manajemen Risiko,Pusaka Setia, Bandung, 2015

\section{Laporan:}

Workshop Kebencanaan Geologi, "Peningkatan Kapasitas Masyarakat di Kawasan Rawan Bencanan Geologi” Kabupaten Batang Jawa Tengah, Novie Noor Afatia, ST. MT. Dkk, PVMBG, Bandung, 2014.

\section{Bahan kuliah:}

Andiani Ir. MSc, Bahan Kuliah Ilmu lingkungan, Bandung, 2016.

\section{Jurnal}

Jazmi Adlan Bohari, I Dewa Ketut Kerta Widana, Jurnal Manajemen Bencana (JMB), 2017. 